\title{
New characid fish, Hyphessobrycon scutulatus, from the rio Teles Pires drainage, upper rio Tapajós system (Ostariophysi: Characiformes: Characidae)
}

\author{
Carlos Alberto Santos de Lucena
}

\begin{abstract}
A new species of characid fish, Hyphessobrycon scutulatus, is described from the rio Teles Pires drainage, upper rio Tapajós system. The new species is distinct from all Hyphessobrycon species by the following characters: inner row premaxillary teeth 7 or 8, all tricuspid; maxilla with 5 to 9 tricuspid teeth; horizontal lateral body stripe or humeral mark absent; and a spot centered on the basal portion of the median caudal-fin rays sometimes extends to the distal portions of those rays.

É descrita uma nova espécie de caracídeo do rio Teles Pires, drenagem do alto rio Tapajós, Hyphessobrycon scutulatus. Distingue-se de todas as demais espécies do gênero pela presença de 7 a 8 dentes tricuspidados na fileira interna do prémaxilar, 5 a 9 dentes tricuspidados no maxilar, ausência de uma faixa escura lateral e de uma mancha umeral e, mancha caudal restrita à base dos raios medianos da nadadeira caudal, as vezes estendendo-se até suas extremidades.
\end{abstract}

Key words: Neotropical, Amazon, taxonomy, fishes.

\section{Introduction}

The genus Hyphessobrycon Durbin (97 spp) along with Astyanax Baird \& Girard (86 spp), Moenkhausia Eigenmann \& Eigenmann (58 spp), Bryconamericus Eigenmann (51 spp), and Hemigrammus Gill (43 spp) taken as a whole include the largest number of currently recognized species among characid fishes that are in need of revision, species counts take from Lima et al. (2003: 106). These genera were originally proposed between 1854 and 1908 and are still more or less defined as by Eigenmann (1917) even though diverse species have been added to each genus since that time. The anatomical diversity within each genus, the fact that each of these generic groups at the present time cannot be well-defined, and the high number of species involved are the major reasons for the lack of phylogenetic analyses dealing with the relationships of the species within these generic "groups." Hyphessobrycon is currently identified by the presence of an adipose fin, incomplete lateral line, two tooth series in the premaxilla, with the teeth of the external series continuous in a single series, teeth not strictly conical, preventral scales arranged in more than one row, and lack of scales in the caudal fin (Eigenmann, 1917; Géry, 1977). However, the phylogenetic significance of these features as used in this definition has not been demonstrated and no phylogenetic diagnosis of Hyphessobrycon is available. This fact does not indicate that these characters have no phylogenetic significance at some levels in a phylogenetic analysis of certain of these species, only that they may not or partly may not be useful in the combination used in the "traditional" definition of Hyphessobrycon. One of the problems concerning a phylogenetic diagnosis of Hyphessobrycon is that the type species, Hyphessobrycon compressus (Meek), comes from the El Hule, Oxaca, basin of the río Papaloapán, Mexico (Weitzman \& Palmer, 1997: 225) and no phylogenetic evidence has been presented that this species is related to species of Hyphessobrycon outside of Central America and perhaps some in northern Colombia west and north of the Andes Mountains. Until such evidence becomes available it seems

Pontifícia Universidade Católica do Rio Grande do Sul, Museu de Ciências e Tecnologia, Laboratório de Ictiologia, Av. Ipiranga 6681, prédio 40, 90619-900 Porto Alegre, RS, Brazil. e-mail: lucena@ pucrs.br 
best to follow tradition and continue to place species that fit the above definition in Hyphessobrycon even though that genus has no current phylogenetic meaning. During a field expedition to Central Brazil, with the exploration of the upper rio Tapajós and rio Xingu, a new characid species was collected that fits the current definition of Hyphessobrycon diagnosis given above.

\section{Material and Methods}

The examined specimens are deposited in the Museu de Ciências e Tecnologia da Pontifícia Universidade Católica do Rio Grande do Sul (MCP). Measurements and counts are as described by Fink \& Weitzman (1974). Morphometric and meristic data were treated with Datax version 4.1. For counts recorded in the description, those of the holotype are given first followed in parentheses by the range, mean, and total number of the specimens counted. Statistical test of differences between the sexes were performed, but no differences were found. Vertebral counts and usually the hooks on anal and ventral-fin rays were taken from specimens cleared, alizarin red and alcian blue stained preparations (c\&s). Vertebral counts include the four vertebra integrated in the Weberian apparatus and the terminal centrum was counted as one vertebra.

\section{Hyphessobrycon scutulatus, new species}

Fig. 1

Holotype. MCP 33333 (male, 34.73 mm SL): Brazil, Mato Grosso: rio Kaiapá, MT 320 road, about 5 km from Nova Canaã do Norte, rio Teles Pires drainage, rio Tapajós system, 10³6'16”'S, 55'42'26”'W; 22 Jan 2002, V. Bertaco, A. Cardoso, L. Malabarba, E. Pereira \& R. Reis.

Paratypes. MCP 32356 (129, 28 counted and measured, 27.55$34.99 \mathrm{~mm} \mathrm{SL}$; 16 females, 27.55-34.99 mm SL and 12 males, 31.46-32.83 mm SL), collected with the holotype. MCP 33729 $(13,27.44-29.10 \mathrm{~mm}$ SL; 7 c\&s, 26.81-32.96 mm SL, one male $26.81 \mathrm{~mm}$ SL) probably from rio Kaiapá, rio Teles Pires drainage, 22-23 Jan 2002, V. Bertaco, A. Cardoso, L. Malabarba, E. Pereira \& R. Reis.

Diagnosis. Differs from all Hyphessobrycon species by the following characters: 7 to 8 tricuspid teeth in the inner premaxillary tooth row; 5 to 9 tricuspid teeth in maxilla; 18 to 21 anal-fin branched rays; small dark spot centered on the basal portion of the median caudal-fin rays, sometimes extending to their distal portions; humeral spot and longitudinal stripe absent; male pelvic fins with hooks; hooks, sometimes present in the anal fin.

Description. Measurements given in Table 1. Body compressed, relatively slender; greatest body depth at dorsal-fin origin. Predorsal profile slightly convex, slightly concave at nape. Dorsal profile nearly straight from dorsal-fin base to just posterior to adipose fin; caudal peduncle dorsal profile slightly concave between adipose fin and dorsal procurrent caudal-fin rays. Dorsal-fin origin distance from snout tip nearly equal or smaller than its distance to anal-fin base. Ventral body profile slightly convex from lower jaw to anal-fin origin; straight along anal-fin base; nearly straight along caudal peduncle. Mouth terminal. Maxilla short, reaching vertical line tangent to anterior border of eye. Obliquus superioris muscle very thin in humeral region with aspect of false pseudotympanum.

Premaxilla with two tooth rows; external row with 3 tricuspid teeth $(2$ to 4 , mean $=2.6, n=30)$; inner row with 8 tricuspid teeth ( 7 to 8,3 specimens with $8, \mathrm{n}=36$ ). Maxilla with 9 tricuspid teeth ( 5 to 9 , mean $=6.3, \mathrm{n}=35$ ); most posterior one or two teeth sometimes conical. Dentary with 15 teeth (12 to 15 , mean $=13, \mathrm{n}=7 \mathrm{c} \& \mathrm{~s}) ; 5$ to 7 anterior teeth larger and tricuspid, followed by 5 to 8 progressively smaller conical teeth.

Dorsal-fin rays ii, $9(\mathrm{n}=36)$. Adipose fin present. Anal-fin rays iii, 19 (iii, $18-21$, mean $=19.0, \mathrm{n}=36$ ), third unbranched, first and second branched rays longer in both males and females. One c\&s male with very small hooks numbering 5 in first, 1 in third and 1 in fourth branched rays. Pectoral-fin rays $\mathrm{i}, 10(\mathrm{i}, 10-12$, mean $=10.5, \mathrm{n}=36$ ); distal tips not reaching pelvic fin. Pelvic-fin rays i,7 $(n=36)$; males with small hooks along posterior border of rays; usually one hook per bony ray segment, rarely two. Principal caudal-fin rays i,17,i $(\mathrm{n}=$ 36).

Lateral line perforated scales $7(7-9$, mean $=7.3, \mathrm{n}=26)$. Longitudinal series of scales, including perforated scales, $32(30-35$, mean $=32.0, n=21)$. Scale rows between lateral line and pelvic-fin origin, 4 (3.5-4 scales, mean $=4.0, n=29)$. Scale rows between lateral line and dorsal-fin origin, 6 (5-6, mean $=5.9, \mathrm{n}=16$ ). Scale rows around caudal peduncle, 14 $(13-15$, mean $=13.6, \mathrm{n}=17)$.

Vertebrae 37 (38 in one specimen), 14-15 precaudal and $17-18$ caudal $(\mathrm{n}=7)$. Upper gill rakers $3(3-5$, mean $=4.0, \mathrm{n}=$ $35)$, lower gill rakers $9(9-11$, mean $=9.5, \mathrm{n}=35)$.

Color in alcohol. Body light brown. A narrow dark line along midbody, from caudal spot to near humeral region, not reaching humeral region in some specimens. Lateral body scales above midlateral line and dorsal scales from supraoccipital process through dorsal procurrent caudalfin rays bordered with black chromatophores forming reticulate pattern. Small dark spot at middle caudal-fin base, either extending or not to their distal tips. Inter radial membranes of dorsal fin darker, mainly in median region, with chromatophores distributed distally; in some specimens basal portion of dorsal fin lighter and chromatophores distributed only distally. Anal and caudal fins darker. Pelvic and pectoral fins lighter, with sparse chromatophores along fin rays. 


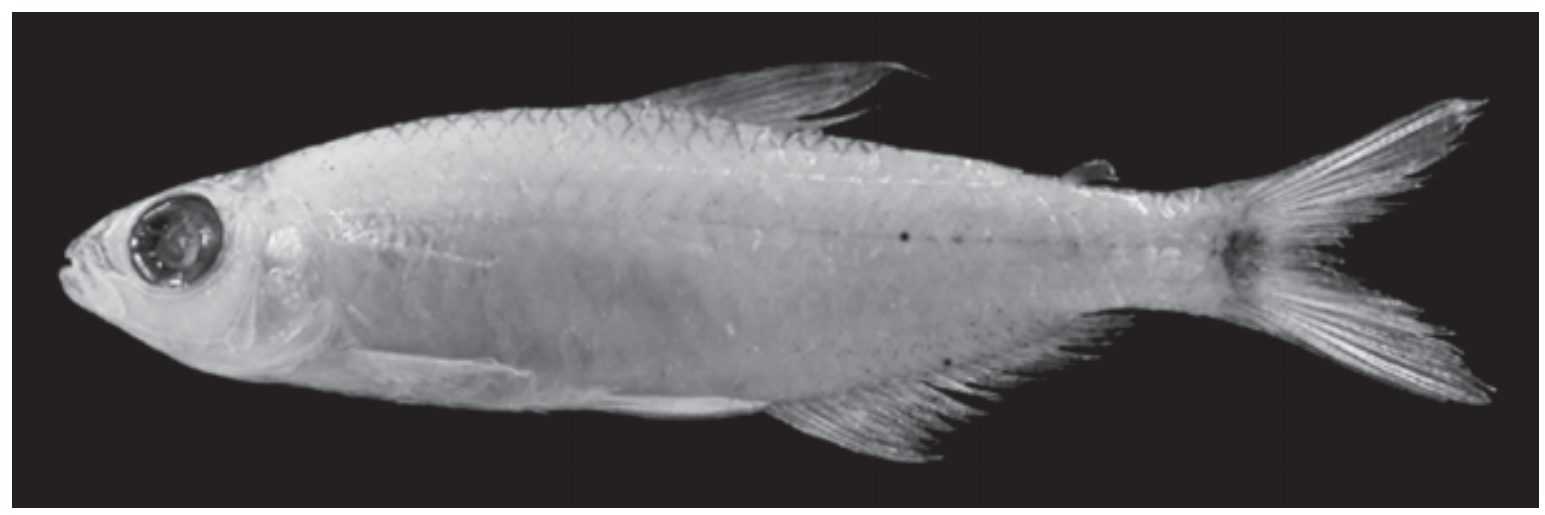

Fig. 1. Hyphessobrycon scutulatus, holotype, MCP 33333, 34.73 mm SL, male, rio Kaiapá, rio Teles Pires drainage, rio Tapajós system.

Distribution. Known only from the type locality, rio Kaiapá drainage, a rio Teles Pires tributary of the rio Tapajós system.

Etymology. The name scutulatus, adjective, from Latin scutula, in allusion to the lozenge or diamond shaped marks formed by the dark lines bordering the scales of the dorsal portion of the body in the specimens.

\section{Discussion}

Both Hyphessobrycon and Hemigrammus are not monophyletic. Their present definitions are not satisfactory even in the typological aspect, since the main character used to distinguish the two genera, the extension of the scales onto the caudal fin occurs in intermediate conditions, as already discussed by Eigenmann (1918), Böhlke (1955), and Weitzman (1977).

The species of Hyphessobrycon have been grouped according to the color pattern of their body and dorsal fin (Eigenmann, 1918; Géry, 1977). According to the color pattern, Hyphessobrycon scutulatus would be placed among the species with a single caudal spot. It is distinguished from all, however, by the presence of 7 to 8 tricuspid teeth in the inner row of the premaxilla ( $v s .5,6$ or 9) and 5 to 9 tricuspid teeth in the maxilla (Fig. 2) (vs. 0 to 3 with more than three cusps).

Two Hyphessobrycon species have been described from the upper rio Tapajós drainage, Hyphessobrycon vilmae Géry (rio Arinos-Juruena basin) and Hyphessobrycon heliacus Moreira, Landim \& Costa (ribeirão Macuco, rio Teles Pires). The last species, according Moreira et al. (2002), may be more closely related to $H$. elachys Weitzman and $H$. loweae Costa \& Géry by sharing elongate dorsal- and pelvic-fin rays in mature males, maxillary teeth multicuspidate, faint humeral spot, and a conspicuous caudal spot all absent in Hyphessobrycon scutulatus. Hyphessobrycon vilmae belongs to the $H$. heterorhabdus-group of Géry (1977) that posses a dark midlateral stripe, absent in Hyphessobrycon scutulatus. Also, H. vilmae is distinguished from Hyphessobrycon scutulatus by the presence of 5 pentacuspidate teeth in the inner premaxillary tooth row and 1 or 3 teeth with four or five cusps in the maxilla.

The lack of a phylogenetic definition for Hemigrammus makes it possible that $H$. scutulatus might be more closely related to one of the species of this genus. According to the identification key presented by Eigenmann (1918:136) and the color pattern criteria of Géry (1977), H. scutulatus would be included among the Hemigrammus species with a caudal spot and usually with a longitudinal lateral band, or line, along the midbody. The new species, however, differs from the species of Hemigrammus having that color pattern by lacking the pigmented caudal-fin lobes, lacking a spot on caudal peduncle ( $v s$. a spot at base of middle caudal-fin rays), absence of a midlateral dark band, presence of tricuspid teeth in the inner tooth series of the premaxilla ( $v s .5$ to 9 cusps), and the maxilla with 5 to 9 teeth (vs. 0 to 4 ).

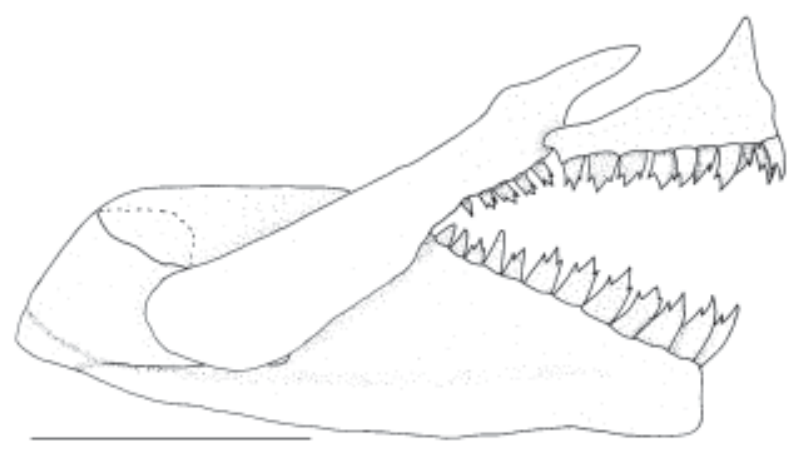

Fig. 2. Hyphessobrycon scutulatus, MCP 33729, $29.09 \mathrm{~mm}$ SL, upper and lower jaws, lateral view, right side, scale $=$ $1.0 \mathrm{~mm}$. 
Table 1. Morphometric data of Hyphessobrycon scutulatus ( $\mathrm{n}=29$ including the holotype; $\mathrm{SD}=$ standard deviation).

\begin{tabular}{lccccc}
\hline \multicolumn{1}{c}{ Characters } & Holotype & \multicolumn{2}{c}{ Range } & Mean & SD \\
\hline Standard length (mm) & 34.7 & 27.4 & 35.0 & 31.4 & 2.0 \\
Percents of standard length & & & & & \\
Body depth & 27.6 & 26.3 & 29.3 & 27.6 & 0.8 \\
Predorsal length & 50.7 & 48.5 & 52.0 & 50.3 & 1.0 \\
Preanal length & 61.0 & 59.5 & 65.6 & 62.2 & 1.6 \\
Prepectoral length & 24.5 & 24.0 & 30.0 & 27.5 & 1.4 \\
Prepelvic length & 46.1 & 43.4 & 51.1 & 46.9 & 1.6 \\
Caudal peduncle length & 15.6 & 12.8 & 17.2 & 15.0 & 1.0 \\
Caudal peduncle depth & 10.1 & 8.7 & 10.6 & 9.7 & 0.5 \\
Dorsal-adipose distance & 25.1 & 21.3 & 27.3 & 24.3 & 1.4 \\
Pelvic-anal distance & 15.8 & 12.0 & 18.1 & 15.8 & 1.3 \\
Pectoral-pelvic distance & 22.2 & 18.2 & 23.1 & 20.5 & 1.4 \\
Anal-fin base length & 28.2 & 25.5 & 31.4 & 28.7 & 1.7 \\
Pelvic-fin length & 17.6 & 13.2 & 17.8 & 15.9 & 1.6 \\
Pectoral-fin length & 17.7 & 14.4 & 28.7 & 17.3 & 2.4 \\
Head length & 25.1 & 25.1 & 29.1 & 27.1 & 0.8 \\
Percents of head length & & & & & \\
Head depth & 71.3 & 69.2 & 81.5 & 73.4 & 3.0 \\
Interorbital width & 29.9 & 23.4 & 30.7 & 27.8 & 1.8 \\
Snout length & 19.5 & 19.2 & 30.6 & 24.9 & 2.4 \\
Eye diameter & 36.8 & 31.3 & 40.3 & 35.4 & 2.1 \\
Upper jaw length & 33.3 & 33.0 & 39.5 & 35.7 & 1.7 \\
\hline
\end{tabular}

Facing the present knowledge about the intrarelationships of the genera of Characidae (Buckup, 1998), especially regarding the species traditionally placed in the Tetragonopterinae sensu latu (Géry, 1977), it is premature to propose a single or alternate meaningful hypothesis of relationships for $H$. scutulatus. It is important to mention, however, that Aphyocharax Günther, Microschemobrycon Eigenmann, and Aphyocharacidium Géry possess representatives bearing more than 5 tricuspid teeth in the premaxilla, 4 or more teeth in the maxilla, reduced number of anal-fin rays, and a interrupted lateral line (except Aphyocharacidium), characters present in H. scutulatus. Those genera, however, possess only one tooth series in the premaxilla. Aphyocharax also has posterior infraorbitals, especially the fourth and fifth ones, large, and occupying nearly the entire region posterior to the orbit. Microschemobrycon, with smaller sized representatives, usually possess a pseudotympanum, ten or more maxillary teeth, and conical or bicuspid teeth. Aphyocharacidium possess a large pseudotympanum, lateral line complete, and two tooth series in the dentary. These characters are absent in Hyphessobrycon scutulatus.

\section{Acknowledgments}

The Central Brazil Expedition was supported by the project "Conhecimento, conservação e utilização racional da diversidade da fauna de peixes do Brasil" (PRONEX/CNPq, proc. 661058/1997-2), coordinated by Naércio A. Menezes. Vinicius Bertaco prepared the specimens for examination of the osteology and José P. da Silva made the photograph. Two anonymous reviewers improved the manuscript with their helpful suggestions.

\section{Literature Cited}

Böhlke, J. E. 1955. Studies on fishes of the family Characidae. - No. 8. The description of a new Hemigrammus from the Rio Negro of Brazil. Transactions of Kansas Academy of Science, 58(1): 229-236.

Buckup, P. A 1998. Relationships of the Characidiinae and phylogeny of characiform fishes (Teleostei: Ostariophysi). Pp. 123-144. In: Malabarba, L. R., R. E. Reis, R. P. Vari, Z. M. Lucena \& C. A. Lucena (Eds.). Phylogeny and classification of Neotropical fishes. Porto Alegre, Edipucrs, 603p.

Eigenmann, C. H. 1917. The American Characidae. Memoirs of Museum of Comparative Zoology, 53(1):1-102 + 101pl.

Eigenmann, C. H. 1918. The American Characidae. Memoirs of Museum of Comparative Zoology, 53(2):103-208 + 89pl.

Fink, W. \& S. H. Weitzman. 1974. The so-called cheirodontin fishes of Central America with descriptions of two new species (Pisces: Characidae). Smithsonian Contributions to Zoology, 172:1-46.

Géry, J. 1977. Characoids of the world. Neptune City, T.F.H. Publications, $672 \mathrm{p}$.

Moreira, C. R., F. C. T. Lima \& W. J. E. M. Costa. 2002. Hyphessobrycon heliacus, a new characid fish (Ostariophysi: Characiformes) from the upper rio Tapajós basin, central Brazil. Copeia, 2002(2): 428-432.

Lima, F. C. T., L. R. Malabarba, P. A. Buckup, J. F. Pezzi da Silva, R. P. Vari, A. Harold, R. Benine, O. T. Oyakawa, C. S. Pavanelli, N. A. Menezes, C. A. S Lucena, M. C. S. L. Malabarba, Z. M. S. Lucena, R. E. Reis, F. Langeani, L. Casatti, V. A. Bertaco, C. Moreira \& P. H. F. Lucinda. 2003. Genera Incertae Sedis in Characidae. Pp. 106-169. In: Reis, R. E., S. O. Kullander \& C. J. Ferraris Jr. (Eds.). Check list of the freshwater fishes of South and Central America. Edipucrs, Porto Alegre, 729p.

Weitzman, S. H. 1977. A new species of characoid fish Hyphessobrycon diancistrus, from the Rio Vichada, Orinoco River drainage, Colombia, South America (Teleostei: Characidae). Proceedings of the Biological Society of Washington, 90(2):348-357.

Weitzman, S. H. \& L. Palmer. 1997. A new species of Hyphessobrycon (Teleostei: Characidae) from the Neblina region of Venezuela and Brazil, with comments on the putative "rose tetra clade". Ichthyological Explorations of Freshwaters, 7(3):209-242.
Received July 2, 2003

Accepted November 17, 2003 